\title{
PENGARUH PROFITABILITAS, LIKUIDITAS, TINGKAT PERTUMBUHAN PERUSAHAAN DAN LEVERAGE TERHADAP KEBIJAKAN DIVIDEN
}

\author{
Putu Sri Puspytha Ratnasari ${ }^{1}$ \\ Ni Ketut Purnawati ${ }^{2}$ \\ ${ }^{1,2}$ Fakultas Ekonomi dan Bisnis Universitas Udayana, Bali, Indonesia \\ email: sripuspytha@gmail.com
}

\begin{abstract}
ABSTRAK
Kebijakan dividen merupakan suatu keputusan mengenai pembagian laba yang diperoleh perusahaan, apakah akan dibagikan kepada pemegang saham atau akan ditahan dalam bentuk laba ditahan untuk membiayai investasi di masa mendatang. Penelitian ini bertujuan untuk menguji pengaruh Profitabilitas, Likuiditas, Tingkat Pertumbuhan Dan Leverage terhadap Kebijakan Dividen pada Perusahaan Manufaktur yang terdaftar di Bursa Efek Indonesia periode 2012 - 2014. Sampel yang diambil sebanyak 16 perusahaan. Metode penentuan sampel yang digunakan dalam penelitian ini adalah purposive sampling. Penelitian ini menggunakan metode asosiatif, teknik analisis regresi linear berganda dan uji parsial (t). Berdasarkan hasil olah data, diperoleh bahwa profitabilitas dan likuiditas berpengaruh positif dan signifikan terhadap kebijakan dividen, tingkat pertumbuhan perusahaan berpengaruh negatif terhadap kebijakan dividen, leverage berpengaruh positif dan tidak signifikan terhadap kebijakan dividen.

Kata Kunci: profitabilitas, ikuiditas, tingkat pertumbuhan perusahaan, leverage, kebijakan dividen
\end{abstract}

\begin{abstract}
Dividend policy is a decision on the division of profits from the company, will be distributed to shareholders or will be retained in the form of retained earnings to finance investment in the future. Study aimed to examine the effect of Profitability, Liquidity, and Leverage Growth rate of the Dividend Policy on Manufacturing Companies listed on the Indonesia Stock Exchange period 2012 - 2014. Samples taken as many as 16 companies. The sampling method used in this research is purposive sampling. This study uses associative method, multiple linear regression analysis and the partial test ( $t$ test). Based on the results if the data was obtained that the profitability and liquidity of positive and significant effect on dividend policy, the growth rate negatively affect the company's dividend policy, leverage and no significant positive effect on dividend policy.
\end{abstract}

Keywords: profitability, liquidity, growth rate, leverage, dividend policy 


\section{PENDAHULUAN}

Kebijakan dividen merupakan salah satu dari tiga keputusan penting yang harus dipertimbangkan manajer dalam suatu perusahaan, yaitu keputusan investasi, pendanaan dan dividen. Kebijakan dividen adalah bagian yang tidak terpisahkan dalam keputusan pendanaan perusahaan Van Horne dan Wachowicsz (dalam Fitriasary 2005:270). Kebijakan dividen merupakan suatu keputusan mengenai pembagian laba yang diperoleh perusahaan, apakah akan dibagikan kepada pemegang saham atau akan ditahan dalam bentuk laba ditahan untuk membiayai investasi di masa mendatang (Sartono, 2010:281).

Kebijakan dividen dapat ditunjukkan dengan Dividen Payout Ratio, yaitu persentase laba yang dibagikan dalam bentuk dividen tunai. Dividend payout ratio adalah persentase laba yang dibayarkan dalam bentuk dividen, atau rasio antara laba yang dibayarkan dalam bentuk dividen dengan total laba yang tersedia bagi pemegang saham. Perusahaan yang memilih membagikan laba dalam bentuk dividen, akan mengurangi total sumber dana internal atau intern financing. Bertentangan dengan keputusan tersebut, perusahaan yang memilih untuk menahan laba yang diperoleh akan mengakibatkan kemampuan pembentukan dana internal yang semakin besar (Sartono, 2010:281).

Seringkali kebijakan dividen menjadi suatu keputusan yang sulit bagi pihak manajemen. Kebijakan ini menyangkut pertimbangan antara dua kepentingan, yaitu kepentingan pemegang saham dengan dividennya serta kepentingan perusahaan dengan laba ditahannya. Hal inilah yang dapat menimbulkan konflik keagenan yang disebabkan oleh perbedaan kepentingan antara pihak manajemen dan para pemegang saham. Hal ini sangat menarik untuk diteliti karena kebijakan dividen yang optimal harus menghasilkan keseimbangan antara dividen saat ini dan pertumbuhan di masa depan yang memaksimalkan harga saham (Brigham dan Houston, 2011:211).

Dalam menginvestasikan dananya para pemegang saham memiliki tujuan, yaitu untuk memperoleh pendapatan (return) baik dalam bentuk dividen maupun capital gain. Pendapatan (return) tersebut tidak didasarkan pada kebijakan manajemen intern perusahaan, tetapi berdasarkan hasil atau kinerja yang telah dicapai oleh perusahaan yang tercermin dalam laporan keuangan yang dipublikasikan (Sandy dan Asyik, 2013). Para investor yang tidak menyukai risiko tinggi akan memilih dividen daripada capital gain di masa yang akan datang dan hanya berorientasi kepada dividen saat ini. Dividen sekarang lebih menguntungkan dibandingkan dengan saldo laba, karena ada kemungkinan nantinya saldo laba tersebut tidak menjadi dividen di masa yang akan datang (Sari, 2008). Berkaitan dengan pendapatan dividen, para investor umumnya menginginkan pembagian dividen yang relatif stabil. Stabilitas dividen akan meningkatkan kepercayaan investor terhadap perusahaan, karena mengurangi ketidakpastian investor dalam menanamkan dananya (Sandi dan Asyik, 2013).

Kebijakan dividen di satu sisi akan memenuhi harapan investor dan disisi lain kebijakan tersebut diharapkan tidak menghambat pertumbuhan perusahaan apalagi mengancam kelangsungan hidup perusahaan. Kebijakan dividen dapat berupa dividen tunai maupun dividen saham, dividen tunai umumnya lebih menarik bagi pemegang saham dibandingkan dengan dividen saham (Sadalia dan Saragih, 2008). 
Pembagian dividen tunai merupakan arus kas keluar dari perusahaan. Hal tersebut mengakibatkan kesempatan perusahaan untuk melakukan investasi dengan kas yang dibagikan sebagai dividen menjadi berkurang (Suharli, 2006). Sisi positifnya, dividen juga merupakan suatu nilai yang mampu mengikat para investor untuk setia terhadap perusahaan tersebut. Beberapa faktor yang diduga memengaruhi kebijakan dividen perusahaan adalah profitabilitas, likuiditas, tingkat pertumbuhan perusahaan dan leverage.

Profitabilitas merupakan salah satu faktor yang mempengaruhi kebijakan dividen. Profitabilitas merupakan kemampuan suatu perusahaan dalam menghasilkan laba. Profitabilitas dalam hal ini diukur menggunakan ROE (Return On Equity), profit yang dihitung adalah profit yang dihasilkan dari ekuitas yang digunakan untuk kegiatan operasional sehingga menghasilkan laba operasional. Semakin tinggi return on equity suatu perusahaan maka dividend payout ratio yang dibagikan juga akan semakin tinggi (Deitiana, 2009).

Beberapa hasil penelitian menemukan bahwa profitabilitas berpengaruh positif dan signifikan terhadap kebijakan dividen, yang ditemukan dalam penelitian Al-najjar (2009), Al-Kuwari (2009), (Marpaung \& Hadianto, 2009), Yudhanto dan Aisjah (2013) serta Silaban (2016). Hasil penelitian Nuringsih (2005) dan Dewi (2008) menemukan bahwa profitabilitas berpengaruh negatif dan signifikan terhadap kebijakan dividen. Menurut penelitian yang dilakukan Apandi (2013), profitabilitas berpengaruh positif dan tidak signifikan terhadap kebijakan dividen. Sementara Anil dan Kapoor (2008), Dhailani (2006), dan (Islam \& Saha, 2014) menemukan bahwa profitabilitas berpengaruh negatif dan tidak signifikan terhadap kebijakan dividen.

Likuiditas merupakan salah satu faktor yang mempengaruhi kebijakan dividen. Rasio likuiditas merupakan rasio yang menunjukkan kemampuan perusahaan untuk melunasi kewajiban jangka pendek dengan aktiva lancar yang dimiliki. Hal ini dikarenakan bagi perusahaan, dividen merupakan arus kas keluar, maka semakin besar posisi kas dan likuiditas perusahaan secara keseluruhan akan semakin besar kemampuan perusahaan untuk membayarkan dividen (Sartono, 2010:293). Likuditas dalam hal ini diproksikan dengan Current Ratio (CR) yaitu rasio antara aktiva lancer dengan utang lancar.

Penelitian yang dilakukan oleh Igan, Aureo dan Marcelo (2006), (Andriyani, 2008), Griffin (2010), Sulistyaningsih (2012), Wicaksana (2012), (Ida Ayu Agung Idawati Drs. Gede Merta Sudiartha, 2011), Dewi (2014) dan Sari (2015) menemukan bahwa likuiditas berpengaruh positif dan signifikan terhadap kebijakan dividen. (Maldajian \& El Khoury, 2014) mengemukakan bahwa likuiditas memiliki pengaruh negatif signifikan terhadap dividend payout ratio. Penelitian yang dilakukan sebelumnya menemukan bahwa likuiditas berpengaruh positif dan tidakk signifikan (Wijanti \& Sedana, 2013). Hasil berbeda ditemukan oleh Novatiani dan Oktaviani (2012), Sunarya (2013), (Lopolusi, 2013) serta Ahmed (2014) bahwa likuiditas berpengaruh negatif tidak signifikan terhadap kebijakan dividen.

Tingkat pertumbuhan perusahaan juga dikatakan merupakan salah satu faktor yang memengaruhi kebijakan dividen. Menurut Rahmawati (2007), pertumbuhan perusahaan yang berkelanjutan adalah tingkat dimana penjualan perusahaan dapat tumbuh tergantung pada bagaimana dukungan asset terhadap peningkatan 
penjualan. Selain melalui tingkat penjualan, pertumbuhan perusahaan dapat juga diukur dari pertumbuhan aset atau dengan kesempatan investasi yang diproksikan melalui berbagai macam kombinasi nilai set kesempatan investasi (investment opportunity set). Dalam hal ini tingkat pertumbuhan perusahaan diproksikan dengan Asset Growth. Pendekatan pertumbuhan perusahaan merupakan suatu komponen untuk menilai prospek perusahaan pada masa yang akan datang. Berdasarkan hal tersebut dapat disimpulkan bahwa pertumbuhan perusahaan merupakan indikator yang tepat untuk menilai prospek perusahaan dimasa yang akan dating (Andriyani, 2008).

Menurut hasil penelitian Sanjaya (2009) dan Murtini (2015) bahwa tingkat pertumbuhan perusahaan berpengaruh positif signifikan terhadap dividend payout ratio. Hatta (2002), Saxena (2002), Corina et al. (2004), Suharli dan Harahap (2004), Sulistiyowati et al. (2010), Fira (2009), Arshad et al. (2013), Dewi (2014) dan Silaban (2016) menyimpulkan bahwa pertumbuhan perusahaan berpengaruh negatif dan signifikan terhadap kebijakan dividen. Penelitian Aivazian (2003) menyatakan tingkat pertumbuhan berpengaruh positif tidak signifikan karena pertumbuhan perusahaan tidak dibiayai oleh laba ditahan melainkan dari sumber dana ekstern. Tingkat pertumbuhan berpengaruh negatif dan tidak signifikan terhadap kebijakan dividen (Lopolusi, 2013).

Leverage atau rasio solvabilitas dikatakan sebagai salah satu variabel yang mempengaruhi kebijakan dividen. Leverage dalam hal ini diproksikan dengan Debt To Equity Ratio (DER). DER merupakan rasio antara total utang dengan total aktiva. Rasio solvabilitas menunjukkan kemampuan dari suatu perusahaan untuk memenuhi segala kewajiban finansial dari perusahaan tersebut seandainya perusahaan tersebut dilikuidasi (Agnes, 2003). Sebuah perusahaan yang rasio utangnya bernilai nol, artinya perusahaan tersebut beroperasi sepenuhnya menggunakan modal sendiri tanpa menggunakan utang. Besarnya porsi penggunaan utang pada struktur modal menggambarkan tingginya jumlah kewajiban yang ditanggung perusahaan. Semakin tinggi kewajiban yang dimiliki perusahaan maka semakin besar kewajiban perusahaan, yang akan menyebabkan semakin kecilnya dividen yang dibagikan, karena laba yang diperoleh dialihkan untuk memenuhi kewajiban perusahaan (Suharli, 2006).

Hasil penelitian Ariyanti (2014), Putera (2011), Anjani (2015) bahwa DER berpengaruh positif dan signifikan terhadap dividend payout ratio. Wibowoputra (2013), Hendrianto (2014), Asiah (2015), dan Sari (2015) menemukan bahwa DER berpengaruh negatif dan signifikan terhadap DPR. Hasil yang berbeda ditemukan oleh Danica (2008) dan Kristianawati (2013) bahwa DER berpengaruh positif dan tidak signifikan terhadap kebijakan dividen. Apandi (2013) menemukan bahwa DER berpengaruh negatif dan tidak signifikan terhadap DPR.

Berdasarkan research gap di atas, penelitian ini memerlukan pengkajian ulang untuk memperjelas temuan selanjutnya. Dipilihnya perusahaan manufaktur karena pada saat ini saham perusahaan manufaktur telah mengalami perkembangan yang pesat diiringi dengan kebutuhan akan logam, makanan dan suku cadang yang tinggi dari masyarakat.

Berdasarkan latar belakang yang telah diuraikan sebelumnya, maka rumusan masalah penelitian ini adalah sebagai berikut: 1) Apakah profitabilitas berpengaruh 
signifikan terhadap kebijakan dividen?; 2) Apakah likuiditas berpengaruh signifikan terhadap kebijakan dividen?; 3) Apakah tingkat pertumbuhan perusahaan berpengaruh signifikan terhadap kebijakan dividen?; 4) Apakah leverage berpengaruh signifikan terhadap kebijakan dividen?

Berdasarkan uraian latar belakang dan rumusan masalah, maka dirumuskan tujuan penelitian sebagai berikut : 1) Untuk mengetahui signifikansi pengaruh profitabilitas terhadap kebijakan dividen; 2) Untuk mengetahui signifikansi pengaruh likuiditas terhadap kebijakan dividen; 3) Untuk mengetahui signifikansi pengaruh tingkat pertumbuhan perusahaan terhadap kebijakan dividen; 4) Untuk mengetahui signifikansi leverage terhadap kebijakan dividen.

Menurut Sartono (2010:281), Kebijakan dividen adalah keputusan apakah laba yang diperoleh perusahaan akan dibagikan kepada pemegang saham sebagai dividen atau akan ditahan dalam bentuk laba ditahan guna pembiayaan investasi dimasa datang. Dividend payout ratio merupakan indikator yang digunakan untuk menguji kebijakan dividen, hal tersebut berdasarkan kebijakan dividen dengan rasio konstan (Sutrisno 2003:306). Menurut Darmadji dan Fakhruddin (2012:159) dividend payout ratio merupakan persentase dari perbandingan dividen per lembar saham dengan laba perlembar saham. Munawir (2002:236) dividend payout ratio mengukur jumlah laba yang diperoleh untuk per lembar saham umum yang dibayarkan dalam bentuk dividen. Warsono (2003:275) mengatakan bahwa, "dividend payout ratio merupakan hasil dari perbandingan antara dividen dengan laba yang tersedia bagi para pemegang saham biasa". Menurut Brigham dan Houston (2011:69) dividend payout ratio adalah persentase dari laba bersih yang akan dibayarkan sebagai dividen tunai kepada pemegang saham.

Setiap perusahaan selalu menginginkan adanya pertumbuhan bagi perusahaan tersebut di satu pihak dan juga dapat membayarkan dividen kepada para pemegang saham di lain pihak, tetapi kedua tujuan tersebut bertentangan. Semakin tinggi tingkat dividen yang dibayarkan, berarti semakin sedikit laba yang dapat ditahan, dan sebagai akibatnya ialah menghambat tingkat pertumbuhan dalam pendapatan dan harga sahamnya. Perusahaan yang ingin menahan sebagian besar dari pendapatannya, berarti bahwa bagian dari pendapatan yang tersedia untuk pembayaran dividen adalah semakin kecil. Persentase dari pendapatan yang akan dibayarkan kepada pemegang saham sebagai cash dividend disebut dividend payout ratio (Riyanto,2011:265). Perusahaan-perusahaan bisnis pada umumnya menggambarkan laba ditahan sebagai sumber pembiayaan investasi di masa mendatang. Hal ini menunjukkan bahwa dividen jelas melibatkan keputusan pembiayaan perusahaan. Modigliani-Miller (MM) berpendapat bahwa di dalam kondisi keputusan investasi yang given, pembayaran dividen tidak berpengaruh terhadap kemakmuran pemegang saham. Lebih lanjut MM berpendapat bahwa nilai perusahaan ditentukan oleh earning power dari aset perusahaan. Akibatnya, nilai perusahaan ditentukan oleh keputusan investasi. Keputusan apakah laba yang diperoleh akan dibagikan dalam bentuk dividen atau akan ditahan tidak memengaruhi nilai perusahaan. MM membuktikan pendapatnya secara matematis dengan berbagai asumsi.

Hal yang penting dari pendapat Modigliani Miller adalah bahwa pengaruh pembayaran dividen terhadap kemakmuran pemegang saham akan diimbangi 
dengan jumlah yang sama dengan cara pembelanjaan atau pemenuhan dana lain. Kondisi keputusan investasi yang given, apabila perusahaan membagikan dividen kepada pemegang saham, perusahaan tersebut harus mengeluarkan saham baru sebagai pengganti sejumlah pembayaran tersebut. Hal tersebut menunjukkan kenaikan pendapatan dari pembayaran dividen akan diimbangi dengan penurunan harga saham sebagai akibat penjualan saham baru. Keputusan mengenai apakah laba yang diperoleh dibagikan sebagai dividen atau akan ditahan dalam bentuk laba ditahan tidak memengaruhi kemakmuran pemegang saham.

Gordon dan Lintner berpendapat bahwa tingkat pengembalian atas ekuitas yang diminta akan turun seiring dengan meningkatnya pembayaran dividen karena kepastian investor dalam menerima keuntungan modal akan turun dari keuntungan modal yang seharusnya diperoleh dari laba ditahan dibandingkan dengan penerimaan dari pembayaran dividen. Modigliani-Miller (MM) menyebut argumentasi Gordon-Lintner sebagai kepercayaan burung di tangan (bird-in-thehand theory) yang salah karena, menurut pendapat MM, sebagian besar investor berencana untuk menginvestasikan kembali dividennya ke dalam saham perusahaan yang sama atau serupa, dan setiap saat tingkat risiko arus kas perusahaan kepada investor dalam jangka panjang akan ditentukan oleh tingkat risiko arus kas operasi, bukan oleh kebijakan pembayaran dividen. Teori MM hanya mengandalkan asumsi tidak adanya pajak dan biaya transaksi, artinya investor yang lebih menyukai dividen hanya perlu menciptakan kebijakan dividennya sendiri dengan menjual sebagian sahamnya setiap tahun. Kenyataanya, sebagian besar investor menghadapi biaya transaksi ketika mereka menjual saham, sehingga investor yang mencari aliran dana yang stabil secara logis akan menyukai perusahaan yang membayarkan dividen secara rutin.

Investor yang dikenai pajak pendapatan perseorangan, pendapatan yang relevan baginya adalah pendapatan setelah pajak. Akibatnya tingkat keuntungan yang disyaratkan juga setelah pajak. Dalam teori ini, disebutkan bahwa apabila capital gain dikenakan pajak dengan tarif lebih rendah daripada pajak atas dividen, maka saham yang memiliki tingkat pertumbuhan tinggi menjadi lebih menarik. Sebaliknya, jika capital gain dikenai pajak yang sama dengan pajak atas dividen, maka keuntungan capital gain menjadi berkurang. Pajak atas capital gain masih lebih baik dibandingkan dengan pajak atas dividen, karena pajak atas capital gain baru dibayar setelah saham dijual sementara pajak atas dividen harus dibayar setiap tahun setelah pembayaran dividen. Periode investasi juga memengaruhi pendapatan investor. Investor yang membeli saham untuk jangka waktu satu tahun, maka tidak ada bedanya antara pajak atas capital gain dan pajak atas dividen. Teori ini menyarankan agar perusahaan lebih baik menentukan dividend payout ratio yang rendah atau bahkan tidak membagikan dividen sama sekali untuk meminimumkan biaya modal dan memaksimumkan nilai perusahaan.

Modigliani-Miller berpendapat bahwa kebijakan dividen adalah tidak relevan dengan mengasumsikan baik investor maupun manajer memiliki informasi yang sama atas kesempatan berbagai peluang investasi. Akibatnya investor maupun manajer memiliki penilaian yang sama terhadap perusahaan dan kebijakan dividen atau kebijakan distribusi pendapatan di masa datang. Kenyataanya, manajer cenderung memiliki informasi lebih baik tentang prospek perusahaan dibandingkan 
dengan investor atau pemegang saham, sehingga investor menilai bahwa capital gain lebih berisiko disbanding dengan dividen dalam bentuk kas.

Dalam praktiknya sering terjadi bahwa pembayaran dividen selalu diikuti dengan kenaikan harga saham sedangkan penurunan dividen akan diikuti dengan penurunan harga saham. Kenyataan ini menunjukkan bahwa investor secara keseluruhan lebih menyukai pembayaran dividen daripada capital gain. Modigliani-Miller melihat kecenderungan ini dengan menyatakan bahwa karena perusahaan cenderung enggan untuk menurunkan tingkat dividen mereka, sehingga perusahaan hanya akan meningkatkan dividen apabila prospek menguntungkan dimasa datang lebih baik atau paling tidak stabil. MM selanjutnya berpendapat bahwa kenaikan dividen ini oleh investor dilihat sebagai tanda atau signal bahwa prospek perusahaan dimasa datang lebih baik. Sebaliknya penurunan dividen akan dilihat sebagai tanda bahwa prospek perusahaan menurun. MM menyatakan bahwa reaksi investor tehadap perubahan dividen tidak berarti bahwa investor lebih menyukai dividen dibanding dengan laba ditahan. Kenyataan bahwa harga saham berubah mengikuti perubahan dividen semata mata karena adanya information content dalam pengumuman dividen.

Profitabilitas merupakan kemampuan perusahaan dalam menghasilkan laba, dan laba inilah yang akan menjadi dasar pembagian dividen perusahaan (Sari, 2008). Perusahaan yang menghasilkan laba memiliki kemampuan untuk membayar dividen sekaligus menyimpan dana internal dalam bentuk laba ditahan untuk membiayai investasi (Al-Makalwi, 2007) dengan syarat laba yang dihasilkan perusahaan tersebut cenderung stabil (Atmaja 2008:292). Semakin tinggi return on equity suatu perusahaan maka dividend payout ratio yang dibagikan juga semakin tinggi (Deitiana, 2009). Semakin tinggi laba yang dihasilkan perusahaan maka semakin tinggi aliran kas dalam perusahaan sehingga perusahaan dapat membayar dividen lebih tinggi (Marpaung \& Hadianto, 2009).

Profitabilitas dalam hal ini diukur dengan ROE, profitabilitas merupakan kemampuan perusahaan dalam menghasilkan laba dengan ekuitas. Laba bersih merupakan faktor utama yang dapat dijadikan pertimbangan untuk memberikan dividen kepada para pemegang saham. Penelitian yang dilakukan oleh Suharli (2007), Abdelsalam et al. (2008), Al-Najjar (2009), Al-Kuwari (2009), Marpaung (2009), Ihejirika dan Nwakanma (2012), Yudhanto dan Aisjah (2013) serta Silaban (2016) menemukan bahwa profitabilitas berpengaruh positif dan signifikan terhadap kebijakan dividen. Hal ini didasarkan pada semakin besar keuntungan yang didapatkan perusahaan, menyebabkan semakin besar jumlah kas yang dimiliki sehingga semakin besar jumlah dividen yang dapat dibagikan kepada pemegang saham (Lopolusi, 2013). Berdasarkan teori dan penelitian terdahulu maka dapat dirumuskan hipotesis sebagai berikut.

$\mathrm{H}_{1}$ : Profitabilitas berpengaruh positif signifikan terhadap Kebijakan Dividen.

Menurut Van Horne dan Wachowicz (2005:167), rasio likuiditas (liquidity ratio) digunakan untuk mengukur kemampuan perusahaan dalam memenuhi liabilitas jangka pendek dengan sumber daya jangka pendek (atau lancar) yang tersedia untuk memenuhi liabilitas tersebut. Weston (2011:127) menyebutkan bahwa rasio likuiditas (liquidity ratio) merupakan rasio yang menggambarkan kemampuan perusahaan dalam memenuhi kewajiban (utang) jangka pendek. 
Artinya apabila perusahaan ditagih, perusahaan akan mampu untuk memenuhi utang tersebut terutama utang yang sudah jatuh tempo, baik kewajiban terhadap pihak luar perusahaan (likuiditas badan usaha) maupun di dalam perusahaan (likuiditas perusahaan).

Posisi kas atau likuiditas dari suatu perusahaan merupakan faktor yang penting yang harus dipertimbangkan sebelum mengambil keputusan untuk menetapkan besarnya dividen yang akan dibayarkan kepada para pemegang saham. Dividen merupakan cash outflow, oleh karena itu semakin kuatnya posisi likuiditas perusahaan, berarti makin besar kemampuan untuk membayarkan dividen.

Nilai current ratio yang tinggi menunjukkan kemampuan pemanfaatan aktiva lancar perusahaan dan kemampuan likuidasi kewajiban lancar secara optimal sehingga keuntungan yang diperoleh perusahaan dapat dibagikan dalam bentuk dividen. Tingkat likuiditas perusahaan yang tinggi mencerminkan tingginya kemampuan perusahaan dalam melunasi hutang yang akan jatuh tempo sehingga akan semakin besar dividen yang dibagikan (Aljannah, 2010)

Penelitian yang dilakukan oleh Griffin (2010), Wicaksana (2012), Andriyani dan Sulistyaningsih (2012), Idawati (2014), Dewi (2014) dan Sari (2015) menyatakan bahwa likuiditas berpengaruh positif dan signifikan terhadap kebijakan dividen. Berdasarkan uraian tersebut, dapat diketahui bahwa semakin kuat posisi likuiditas perusahaan terhadap prospek kebutuhan dana di waktu-waktu mendatang, maka semakin tinggi pula tingkat dividend payout ratio-nya (Riyanto, 2011:267). Berdasarkan teori dan penelitian terdahulu maka dapat dirumuskan hipotesis sebagai berikut.

$\mathrm{H}_{2}$ : Likuiditas berpengaruh positif signifikan terhadap Kebijakan Dividen.

Rasio pertumbuhan (growth) adalah rasio yang mengukur seberapa besar kemampuan perusahaan dalam mempertahankan posisinya didalam industri dalam pengembangan ekonomi secara umum (Sartono, 2010:65). Pertumbuhan dinyatakan sebagai pertumbuhan total aset dimana pertumbuhan aset pada masa lalu akan menggambarkan profitabilitas di masa mendatang dan pertumbuhan mendatang (Kusumajaya, 2011), jadi tingkat pertumbuhan perusahaan merupakan perubahan total aset baik berupa peningkatan atau penurunan yang dialami perusahaan selama satu periode (satu tahun).

Pertumbuhan perusahaan merupakan salah satu faktor yang memengaruhi kebijakan dividen. Semakin cepat tingkat pertumbuhan perusahaan maka semakin besar kebutuhan dana yang diperlukan untuk membiayai pertumbuhan perusahaan (Marpaung \& Hadianto, 2009). Semakin besar kebutuhan dana untuk waktu mendatang perusahaan lebih senang untuk menahan labanya daripada membayarkannya dalam bentuk dividen kepada para pemegang saham (Riyanto, 2001:268). Hal ini dikarenakan biaya modal dengan menggunakan laba ditahan lebih murah dibandingkan dengan berbagai sumber pembiayaan lainnya seperti penerbitan saham baru maupun obligasi (Gitman 2006:502). Suatu perusahaan yang memiliki tingkat pertumbuhan yang tinggi cenderung membutuhkan dana yang besar dan melakukan pembuatan keputusan yang berkaitan dengan bagaimana dana yang diperoleh tersebut diinvestasikan (Handayani \& Indahningrum, 2009).

Oleh karena itu perusahaan yang memiliki tingkat pertumbuhan yang tinggi akan memiliki rasio pembayaran dividen yang rendah (Hanafi 2004:44). Hal itu 
didukung dengan penelitian yang dilakukan oleh Gugler (2003) dan Latiefsari (2011), Saxena (2002), Corina et al. (2004), Suharli dan Harahap (2004), Fira (2009), Sulistiyowati et al. (2010), serta Silaban (2016) yang menemukan bahwa tingkat pertumbuhan perusahaan berpengaruh negative dan signifikan terhadap kebijakan. Dalam penelitian ini pertumbuhan perusahaan diproksikan dengan pertumbuhan aset. Berdasarkan teori dan penelitian terdahulu maka dapat dirumuskan hipotesis sebagai berikut.

$\mathrm{H}_{3}$ : Tingkat Pertumbuhan berpengaruh negatif signifikan terhadap Kebijakan Dividen.

Berdasarkan rumusan hipotesis dan studi empiris maka dapat dibuat kerangka konseptual sebagai berikut:

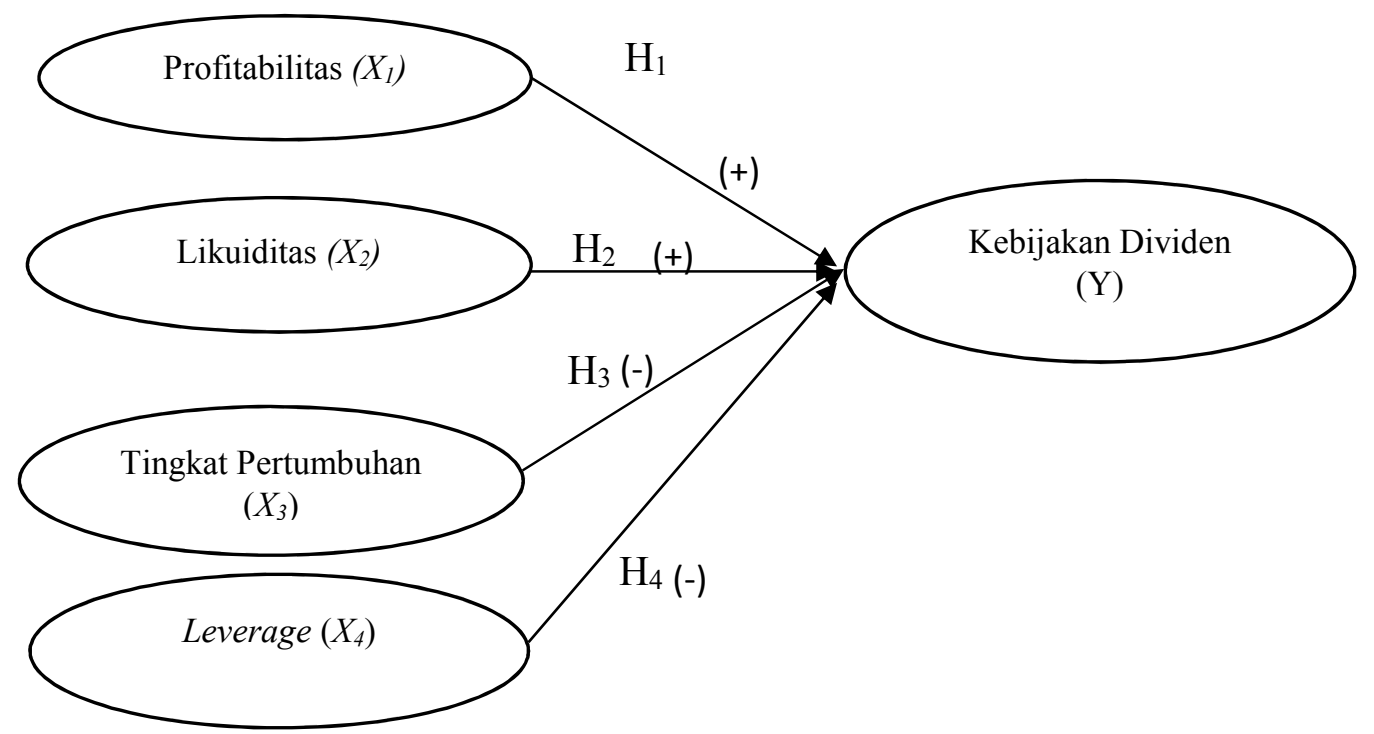

\section{Gambar 1. Kerangka Konseptual}

Sumber: Data Diolah, 2016

Warsono (2003:204) menyatakan bahwa leverage adalah penggunaan asset atau dana, dan sebagai konsekuensinya perusahaan harus mengeluarkan biaya dan beban tetap. Sedangkan menurut Sawir (2009:60) menyatakan rasio leverage adalah rasio yang menunjukkan kemampuan perusahaan untuk memenuhi segala kewajiban finansialnya apabila perusahaan pada saat itu dilikuidasi. Leverage dikatakan sebagai salah satu faktor yang memengaruhi kebijakan dividen. Leverage dapat dihitung menggunakan debt to equity ratio atau biasa disingkat dengan DER. Debt to equity ratio merupakan rasio utang terhadap modal, Ross et al. (2003) menyatakan bahwa "debt to equity ratio is dividing total debt with total equity" rasio ini merupakan rasio solvabilitas atau leverage yang mengukur kemampuan kinerja perusahaan dalam mengambil utang jangka panjangnya dengan melihat perbandingan antara total utang dengan total equitasnya.

Perusahaan dengan prospek yang baik cenderung akan menggunakan hutang untuk membiayai kegiatan ekspansi perusahaan, apabila perusahaan tidak mempunyai dana internal untuk memenuhi kebutuhan dana tersebut. Pelunasan hutang pada jatuh tempo menuntut perusahaan menyediakan dana dengan cara 
melakukan penyimpanan laba. Semakin besar hutang yang harus dilunasi, semakin besar pula dana yang harus disediakan oleh perusahaan. Besarnya dana yang mesti disediakan perusahaan untuk melunasi hutang, akan berakibat pada berkurangnya deviden yang akan dibayarkan kepada pemegang saham (Latibo, 2014). Besarnya porsi utang pada struktur modal menggambarkan tingginya jumlah kewajiban yang ditanggung perusahaan, karena akan menimbulkan beban bunga yang besar.

Semakin besar hutang perusahaan maka, deviden payout ratio akan semakin kecil. Pernyataan ini didukung dengan penelitian Akhadiyah (2015) Asiah (2015), Wibowoputra (2013) serta Hendrianto (2013) yang menyatakan bahwa leverage berpengaruh negatif dan signifikan terhadap kebijakan dividen. Berdasarkan teori dan penelitian terdahulu maka dapat dirumuskan hipotesis sebagai berikut. $\mathrm{H}_{4}$ : Leverage berpengaruh negatif signifikan terhadap Kebijakan Dividen.

\section{METODE PENELITIAN}

Penelitian ini termasuk dalam jenis penelitian asosiatif. Penelitian yang bertujuan untuk mengetahui pengaruh atau juga hubungan antara dua variabel atau lebih. Variabel dependent yang digunakan dalam penelitian ini adalah kebijakan dividen, sedangkan variabel independent adalah Profitabilitas, Likuiditas, Tingkat Pertumbuhan, dan Leverage. Penelitian ini dilakukan pada perusahaan manufaktur yang terdaftar di Bursa Efek Indonesia (BEI).

Kebijakan dividen diukur dengan Dividend Payout Ratio. Dividend Payout Ratio merupakan rasio antara dividen per lembar saham dengan laba per lembar saham pada perusahaan manufaktur yang terdaftar di Bursa Efek Indonesia (BEI) periode 2012-2014. DPR dapat dirumuskan sebagai berikut (Tandelilin, 2010:385).

$$
\text { Dividend Payout Ratio }=\frac{\text { Dividend Per Share }}{\text { Earning Per Share }} \times 100 \%
$$

Profitabilitas diukur dengan Return On Equity (ROE). ROE merupakan rasio antara laba bersih setelah pajak dengan modal sendiri pada perusahaan manufaktur yang terdaftar di BEI periode 2012-2014. ROE dapat dirumuskan sebagai berikut (Kasmir, 2011:204).

$$
R O E=\frac{\text { Earning After } \operatorname{Tax}}{\text { Equity }} \times 100 \%
$$

Rasio likuiditas dalam penelitian ini diukur dengan Current Ratio. Current ratio merupakan rasio antara aktiva lancar dengan utang lancar pada perusahaan manufaktur periode 212-2014. Satuan pengukuran current ratio adalah dalam persentase. Current Ratio dapat dirumuskan sebagai berikut (Wiagustini, 2010).

$$
\text { Current Ratio }=\frac{\text { Current Asset }}{\text { Current Liabilities }} \times 100 \%
$$

Tingkat pertumbuhan perusahaan (growth) merupakan suatu komponen untuk menilai prospek perusahaan pada masa yang akan datang (Murni dan Adriana, 2007). Rasio ini akan diteliti pengaruhnya terhadap kebijakan dividen pada perusahaan-perusahaan yang tergabung dalam perusahaan Manufaktur selama periode pengamatan yaitu 2012-2014. Secara sistematis tingkat pertumbuhan perusahaan dapat dirumuskan sebagai berikut.

$$
\text { Growth }=\frac{\text { Total Aset } t-\text { Total Aset } t-1}{\text { Total Aset } t-1}
$$


Rasio leverage yang digunakan dalam hal ini adalah Debt to Equity Ratio yang mebandingkan total utang dengan total modal. Penggunaan DER dalam penelitian ini dikarenakan DER adalah rasio yang paling tepat untuk menggambarkan struktur modal perusahaan dan dapat menunjukkan kondisi keuangan perusahaan, sehingga dapat memengaruhi besarnya dividen yang dibayarkan. Secara matematis Debt To Equity Ratio dapat dirumuskan sebagai berikut (Wiagustini, 2010:79).

$$
\text { DER }=\frac{\text { Total Debt }}{\text { Total Equity }} \times 100
$$

Data kualitatif yang digunakan dalam penelitian ini adalah gambaran umum perusahaan manufaktur. Data kuantitatif yang digunakan dalam penelitian ini adalah laporan keuangan perusahaan manufaktur periode 2012-2014 yang terdaftar di Bursa Efek Indonesia. Populasi dalam penelitian ini adalah seluruh perusahaan manufaktur yang terdaftar di Bursa Efek Indonesia periode tahun 2012-2014. Jumlah populasi yang didapatkan dalam penelitian ini adalah sebanyak empat ratus delapan puluh dua perusahaan. Metode penentuan sampel menggunakan purposive sampling.

Penelitian ini menggunakan teknik analisis regresi linier berganda. Teknik regresi linier berganda merupakan pengolahan data dimana teknik ini digunakan untuk mengestimasi nilai variabel dependent dengan menggunakan lebih dari satu variabel independent. Persamaan regresi linier berganda ditunjukan sebagai berikut

$$
Y=\alpha+\beta_{1} X_{1}+\beta_{2} X_{2}+\beta_{3} X_{3}+\beta_{4} X_{4}+\text { ei. }
$$

\begin{tabular}{|c|c|}
\hline$\alpha$ & $=$ Konstanta \\
\hline Y & $=$ Kebijakan Dividen \\
\hline$\beta_{1,2,3,4,5 . . \mathrm{i}}$ & $=$ Koefisien regresi masing-masing $\mathrm{X}_{\mathrm{i}}$ \\
\hline $\mathrm{X}_{1}$ & $=$ Profitabilitas \\
\hline $\mathrm{X}_{2}$ & $=$ Likuiditas \\
\hline $\mathrm{X}_{3}$ & $=$ Tingkat Pertumbuhan \\
\hline $\mathrm{X}_{4}$ & $=$ Leverage \\
\hline 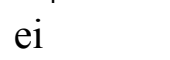 & $=$ Variabel pengganggu (Residual Error) \\
\hline
\end{tabular}

Keterangan :

\section{HASIL DAN PEMBAHASAN}

Pada tabel 1. dapat diketahui statistik deskriptif masing-masing variabel. Pada tabel 1. berdasarkan data dari 16 perusahaan selama 3 tahun menunjukkan bahwa rata-rata kemampuan perusahaan menghasilkan laba bersih dengan modal yang dimiliki sebesar 34,8\% dengan nilai minimum ROE yang diperoleh sebesar 7,64 dan nilai maksimum mencapai 125,81 .

Berdasarkan Tabel 1. tingkat rata-rata Current Ratio perusahaan sebesar 195,4\% dengan nilai minimum Current Ratio sebesar 45 dan maksimum sebesar 772,6. Rata-rata tingkat pertumbuhan aset perusahaan selama 3 tahun sebesar $19,01 \%$, dengan nilai minimum $-37,5$ dan maksimum sebesar $90,7 \%$. Tingkat ratarata rasio utang terhadap modal perusahaan selama 3 tahun sebesar $0,81 \%$ dengan nilai minimum sebesar 0,21 dan nilai maksimum sebesar 2,36. Tingkat rata-rata pembagian dividen 16 perusahaan manufaktur selama 3 tahun sebesar 57,1\% dengan nilai minimum 24,68 dan maksimumnya sebesar 99,96. 
Tabel 1.

Hasil Statistik Deskriptif

\begin{tabular}{cccccc}
\hline Variabel & Mean & Min & Max & Std Deviasi & N \\
\hline ROE & 34.8354 & 7.64 & 125.81 & 26.54061 & 48 \\
Current Ratio & 195.4556 & 45.00 & 772.65 & 119.43068 & 48 \\
Asset Growth & 19.0188 & -37.54 & 90.78 & 14.92683 & 48 \\
DER & 0.8177 & 0.21 & 2.36 & 0.48838 & 48 \\
DPR & 57.1371 & 24.68 & 99.96 & 19.45248 & 48 \\
\hline
\end{tabular}

Tabel 2.

Hasil Uji Normalitas

\begin{tabular}{ccc}
\hline & & $\begin{array}{c}\text { Unstandardized } \\
\text { Residual }\end{array}$ \\
\hline$N$ & Mean & 48 \\
Normal Parameters $^{a, b}$ & Std. Deviation & .0000000 \\
Most Extreme & Absolute & 13.53762274 \\
Difference & Positive & .172 \\
Kolmogorov-Smirnov $Z$ & Negative & .172 \\
Asymp. Sig. (2-tailed) & & -.080 \\
\hline Sumber: Data diolah, 2016 & & 1.191 \\
\end{tabular}

Hasil uji normalitas pada penelitian ini ditunjukkan pada Tabel 2. berikut menunjukkan bahwa nilai Kolmogorov-Smirnov (K-S) adalah sebesar 1,191 dan nilai Asymp. Sig. (2-tailed) adalah sebesar 0,117. Nilai Asymp. Sig. (2-tailed) 0,552 $>0,05$, ini berarti menunjukkan bahwa residual dari model regresi yang berdistribusi normal.

Berdasarkan Tabel 3. dapat diketahui nilai Durbin Watson (D-W) sebesar 2,151. Nilai tersebut berada diantara $d_{u}=1,720$ dan $4-d_{u}=2,280$ atau $1,720<$ $2,151<2,280$ yang merupakan daerah bebas autokorelasi atau model regresi yang dibuat tidak mengandung gejala autokorelasi.

Tabel 3.

Hasil Uji Autokorelasi

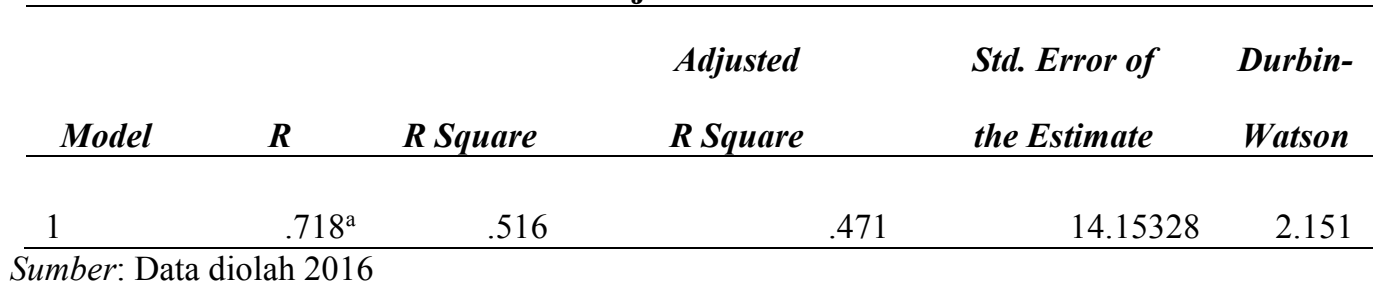

Berdasarkan Tabel 4. dapat diketahui bahwa nilai tolerance dari ROE adalah sebesar 0,465 atau 46,5 persen, CR sebesar 0,956 atau 95,6 persen, AG sebesar 
0,988 atau 98,8 persen, dan DER sebesar 0,478 atau 47,8 persen. Nilai tersebut menunjukkan bahwa nilai tolerance masing-masing variabel lebih besar dari 10 persen. Nilai VIF dari variabel ROE, CR, AG, dan DER berturut-turut sebesar 2,$105 ; 1,047 ; 1,012$; dan 2,093 dimana masing-masing variabel nilainya lebih kecil dari 10 yang berarti bahwa model regresi bebas dari multikolinearitas.

Tabel 4.

Hasil Uji Multikolinearitas

\begin{tabular}{llll}
\hline Model & & \multicolumn{2}{c}{ Collinierity Statistics } \\
Tolerance & VIF \\
\hline 1 & (Constant) & & \\
& ROE & .465 & 2.105 \\
& CR & .956 & 1.047 \\
AG & .988 & 1.012 \\
& DER & .478 & 2.093 \\
\hline
\end{tabular}

Sumber: Data diolah, 2016

Uji heterokedastisitas dapat dilakukan dengan uji glejser, jika probabilitas signifikansi yang diperoleh di atas tingkat signifikansi yang digunakan $(0,05)$ maka dapat disimpulkan bahwa model regresi tersebut tidak terjadi heterokedastisitas. Berdasarkan Tabel 5. diketahui bahwa nilai Sig. ROE, CR, AG, dan DER lebih besar dari 0,05 . Hal ini berarti bahwa tidak terdapat pengaruh antara variabel bebas terhadap absolute residual, sehingga model yang dibuat tidak mengandung gejala heterokedastisitas.

Tabel 5.

Hasil Uji Heterokedastisitas

\begin{tabular}{llcc} 
Model & & \multicolumn{2}{c}{ Sig. } \\
\hline 1 & (Constant) & 3.527 & .001 \\
& ROE & 1.438 & .158 \\
& CR & .229 & .820 \\
& AG & -.960 & .342 \\
& DER & -1.936 & .059 \\
\hline
\end{tabular}

Analisis regresi linier berganda digunakan untuk mengetahui arah dan besarnya pengaruh ROE, CR, AG, dan DER terhadap DPR pada perusahaan manufaktur yang terdaftar di Bursa Efek Indonesia periode 2012 - 2014.

Pada Tabel 6. diketahui bahwa Nilai koefisien determinasi $\left(\mathrm{R}^{2}\right)$ sebesar 0,516 menunjukkan bahwa 51,6 persen variabel-variabel kebijakan dividen dapat dijelaskan oleh variabel profitabilitas (X1), likuiditas (X2), tingkat pertumbuhan perusahaan (X3) dan leverage $\left(\mathrm{X}_{4}\right)$ sedangkan sisanya sebesar 48,4 persen dijelaskan oleh variabel lain yang tidak termasuk di dalam penelitian ini. 
Tabel 6.

Hasil Koefisien Determinasi Majemuk $\left(\mathbf{R}^{2}\right)$

\begin{tabular}{cccccc}
\hline Model & R & R Square & $\begin{array}{c}\text { Adjusted R } \\
\text { Square }\end{array}$ & $\begin{array}{c}\text { Std. Error of } \\
\text { the Estimate }\end{array}$ & $\begin{array}{c}\text { Durbin } \\
\text { Watson }\end{array}$ \\
\hline 1 & $0.718^{\mathrm{a}}$ & 0.516 & 0.471 & 14.15328 & 2.151 \\
\hline
\end{tabular}

Sumber: Data diolah, 2016

Tabel 7.

Hasil Analisis Regresi Linier Berganda

\begin{tabular}{lrrrrr}
\hline \multicolumn{1}{c}{ Model } & $\begin{array}{c}\text { Unstandardized Coefficients } \\
\text { B }\end{array}$ & $\begin{array}{c}\text { Standardized } \\
\text { Coefficients } \\
\text { Beta }\end{array}$ & T & Sig. \\
\hline (Constant) & 40.467 & 6.002 & & 6.742 & .000 \\
ROE & .413 & .114 & .564 & 3.624 & .001 \\
CR & .059 & .018 & .361 & 3.321 & .002 \\
AG & -.496 & .139 & -.381 & -3.568 & .001 \\
Ukuran Perusahaan & .283 & 6.115 & .007 & .046 & .963 \\
\hline
\end{tabular}

Sumber: Data diolah, 2016

Maka dapat diketahui persamaan regresi adalah sebagai berikut:

$\mathrm{Y}=40,467+0,413 \mathrm{X}_{1}+0,059 \mathrm{X}_{2}-0,496 \mathrm{X}_{3}+0,283 \mathrm{X}_{4}+\varepsilon$

$\alpha=$ Nilai konstanta sebesar 40.467 menunjukkan bahwa jika profitabilitas $\left(\mathrm{X}_{1}\right)$,

likuiditas $\left(\mathrm{X}_{2}\right)$, Tingkat Pertumbuhan $\left(\mathrm{X}_{3}\right)$ dan Leverage $\left(\mathrm{X}_{4}\right)$ sama dengan nol, maka nilai dividen payout ratio meningkat 40,467 persen, $b_{1}=$ Nilai koefisien profitabilitas sebesar 0,413 menunjukkan apabila profitabilitas meningkat satu persen, mengakibatkan kenaikan kebijakan dividen (Y) sebesar 0,413 persen dengan asumsi variabel lainnya konstan, $b_{2}=$ Nilai koefisien likuiditas sebesar 0,059 menunjukkan apabila likuiditas meningkat satu persen, mengakibatkan kenaikan kebijakan dividen (Y) sebesar 0,059 dengan asumsi variabel lainnya konstan, $b_{3}=$ Nilai koefisien tingkat pertumbuhan $\left(b_{3}\right)$ sebesar $-0,496$ menunjukkan bahwa apabila tingkat pertumbuhan meningkat satu persen, akan mengakibatkan penurunan kebijakan dividen $(\mathrm{Y})$ sebesar -0,496 dengan asumsi variabel lainnya konstan, $\mathrm{b}_{5}=$ Nilai koefisien leverage $\left(\mathrm{b}_{4}\right)$ sebesar 0,283 menunjukkan bahwa apabila tingkat pertumbuhan meningkat satu persen, akan mengakibatkan kenaikan kebijakan dividen (Y) sebesar 0,283 dengan asumsi variabel lainnya konstan.

Hipotesis pertama menunjukkan bahwa profitabilitas berpengaruh positif dan signifikan terhadap kebijakan dividen. Hasil pengujian hipotesis menunjukkan bahwa $\mathrm{H}_{0}$ ditolak dan $\mathrm{H}_{1}$ diterima dengan signifikansi 0,001 yang lebih kecil dari taraf signifikansi yang ditentukan sebesar 0,05 . Ini menunjukkan bahwa semakin tinggi kemampuan perusahaan menghasilkan laba, maka perusahaan akan meningkatkan pembayaran dividen. Hal ini juga sesuai dengan Teori Bird in The Hand menyatakan bahwa para investor lebih menyukai income dalam bentuk dividen dibandingkan dengan dalam bentuk capital gain, kenyataannya sebagian besar investor menghadapi biaya transaksi ketika mereka menjual saham, sehingga 
investor yang mencari aliran dana yang stabil secara logis akan memilih perusahaan yang membayarkan dividen secara rutin.

Hasil penelitian ini sejalan dengan hasil penelitian sebelumnya seperti penelitian Yudhanto dan Aisjah (2013), (Lopolusi, 2013), Idawati (2014) serta Silaban (2016) yang menyatakan bahwa adanya pengaruh positif dan signifikan antara profitabilitas dengan kebijakan dividen, namun bertentangan dengan hasil penelitian dari (Islam \& Saha, 2014) serta Sari (2015) yang menyatakan bahwa profitabilitas berpengaruh negatif dan tidak signifikan terhadap kebijakan dividen.

Hipotesis Kedua menyatakan bahwa likuiditas berpengaruh positif dan signifikan terhadap kebijakan dividen. Hasil pengujian hipotesis menunjukkan Ho ditolak dan $\mathrm{H}_{1}$ diterima dengan signifikansi 0,002 yang lebih kecil dari taraf signifikansi yang ditentukan sebesar 0,05 . Nilai current ratio yang tinggi menunjukkan kemampuan pemanfaatan aktiva lancar perusahaan dan kemampuan likuidasi kewajiban lancar secara optimal sehingga keuntungan yang diperoleh perusahaan dapat dibagikan dalam bentuk dividen. Tingginya tingkat likuiditas perusahaan menggambarkan tingginya kemampuan perusahaan dalam pelunasan hutang yang akan segera jatuh tempo sehingga semakin besar dividen yang akan dibagikan (Aljannah, 2010).

Hasil penelitian ini sejalan dengan penelitian yang dilakukan oleh Mehta (2012), Idawati (2014), Aljannah (2010) dan Sari (2015) yang menyatakan bahwa likuiditas berpengaruh positif dan signifikan terhadap kebijakan dividen, namun bertentangan dengan hasil penelitian (Maldajian \& El Khoury, 2014) yang mengemukakan bahwa likuiditas memiliki pengaruh negatif signifikan, penelitian (Wijanti \& Sedana, 2013) bahwa likuiditas berpengaruh positif dan tidak signifikan serta Sunarya (2013) yang menyatakan likuiditas berpengaruh negatif dan tidak signifikan.

Hipotesis ketiga menyatakan bahwa tingkat pertumbuhan perusahaan berpengaruh negatif dan signifikan terhadap kebijakan dividen. Hasil pengujian hipotesis yang diperoleh menunjukkan bahwa bahwa Ho ditolak dan $\mathrm{H}_{1}$ diterima dengan signifikansi 0,001 yang lebih kecil dari taraf signifikansi yang ditentukan 0,05 dengan demikian pertumbuhan perusahaan berpengaruh negatif terhadap kebijakan dividen. Semakin tinggi tingkat pertumbuhan perusahaan maka akan semakin kecil jumlah dividen yang dibagikan kepada para pemegang saham karena besarnya tingkat kebutuhan dana perusahaan. Asset growth sering dialokasikan untuk kegiatan operasional sehingga banyak asset perusahaan ditahan. Semakin tinggi tingkat pertumbuhan perusahaan maka akan semakin besar tingkat kebutuhan dana untuk membiayai total perusahaan. Adanya penambahan laba yang ditahan berarti ada penambahan modal sendiri dalam perusahaan yang diperoleh dengan biaya murah.Sehingga pihak manajer lebih memilih untuk membiayai ekspansi atau pertumbuhan perusahaan daripada dibayarkan dalam bentuk dividen Hasil penelitian ini sejalan dengan hasil penelitian yang dilakukan oleh Arshad et al. (2013) dan Silaban (2016) yang menyatakan bahwa asset growth berpengaruh negatif dan signifikan terhadap kebijakan dividen dan bertentangan dengan hasil yang ditemukan oleh Murtini (2015) bahwa tingkat pertumbuhan perusahaan berpengaruh positif signifikan terhadap dividend payout ratio, penelitian Aivazian (2003) yang menyatakan tingkat pertumbuhan berpengaruh positif tidak signifikan 
serta penelitian (Lopolusi, 2013) yang menyatakan bahwa tingkat pertumbuhan berpengaruh negatif dan tidak signifikan terhadap kebijakan dividen.

Hipotesis keempat menyatakan bahwa Leverage berpengaruh negatif dan signifikan terhadap kebijakan dividen. Hasil pengujian hipotesis yang diperoleh menunjukkan Ho diterima dan $\mathrm{H}_{1}$ ditolak dengan signifikansi 0,963 yang lebih besar dari taraf signifikansi yang ditentukan 0,05 dengan demikian leverage berpengaruh positif dan tidak signifikan terhadap kebijakan dividen. Hasil penelitian ini menunjukkan bahwa kemampuan pembayaran dividen tidak dipengaruhi oleh besarnya hutang yang dimiliki perusahaan. Hal ini disebabkan oleh komitmen perusahaan manufaktur untuk melakukan pembayaran dividen secara teratur, bahkan kenaikan hutang dapat meningkatkan kemampuan pembayaran dividen selama penggunaan hutang diiringi dengan peningkatan laba perusahaa (Danica, 2008). Hal ini sesuai dengan teori keuangan yang menyatakan jangan lakukan hutang baru jika tidak menghasilkan tambahan laba.

Hasil penelitian ini sejalan dengan penelitian Apandi (2013), Danica (2008), dan Prawira (2015) yang menyatakan bahwa Debt to Equity Ratio berpengaruh positif dan tidak signifikan terhadap kebijakan dividend dan bertentangan dengan penelitian Ariyanti (2014) dan Anjani (2015) bahwa DER berpengaruh positif dan signifikan terhadap kebijakan dividen, penelitian Wibowoputra (2013), Hendrianto (2014) yang menemukan bahwa DER berpengaruh negatif dan signifikan terhadap DPR serta penelitian apandi yang menyatakan bahwa DER berpengaruh negatif dan tidak signifikan.

\section{SIMPULAN}

Berdasarkan pembahasan hasil penelitian ini maka dapat ditarik simpulan sebagai berikut. 1) Profitabilitas berpengaruh positif dan signifikan terhadap dividend payout ratio, hal ini membuktikan bahwa semakin ting gi profitabilitas perusahaan maka semakin besar jumlah dividen yang diterima oleh para pemegang saham. 2) Likuiditas berpengaruh positif dan signifikan terhadap dividend payout ratio, hal ini membuktikan bahwa semakin tinggi likuiditas perusahaan maka semakin tinggi jumlah dividen yang dibagikan. 3) Tingkat pertumbuhan perusahaan berpengaruh negatif dan signifikan terhadap dividen payout ratio, hal ini membuktikan bahwa semakin tinggi tingkat pertumbuhan perusahaan maka semakin rendah tingkat dividen yang dibayarkan oleh perusahaan. 4) Leverage berpengaruh positif dan tidak signifikan terhadap kebijakan dividen, hal ini membuktikan bahwa tingkat hutang yang dimiliki perusahaan tidak mempengaruhi besar kecilnya dividen yang dibagikan kepada para pemegang saham.

Berdasarkan pembahasan hasil penelitian dan simpulan di atas, maka saran yang dapat diberikan adalah sebagai berikut. 1) Bagi investor agar lebih memperhatikan aspek profitabilitas, likuiditas, dan tingkat pertumbuhan dalam berinvestasi karena faktor tersebut berpengaruh signifikan terhadap dividend payout ratio. 2) Bagi peneliti selanjutnya diharapkan dapat menambah sampel perusahaan dan menambahkan subyek perusahaan lain selain manufaktur.

\section{REFERENSI}

Andriyani, M. (2008). Analisis Pengaruh Cash Ratio, Debt To Equity Ratio , 
Insider Ownership, Investment Opportunity Set ( Ios ), Dan Profitability Terhadap Kebijakan Dividen ( Studi Empiris pada perusahaan Automotive di Bursa Efek Indonesia Periode Tahun 2004-2006). Tesis Universitas Diponegoro.

Anil, K., dan Kapoor, S. 2008. Determinant of Dividend Payout Ratio - A Study of Indian Information Technology Sector, International Research Journal of Finance and Economics, 15, 63-71.

Anjani, Nurvi T. 2015. Pengaruh Cash Position, Firm Size, Debt To Equity Ratio, Dan Return On Asset Terhadap Dividend Payout Ratio Pada Perusahaan Manufaktur yang Terdaftar Di Bursa Efek Indonesia. Skripsi. Jurusan Manajemen Universitas Negeri Yogyakarta.

Arshad, Zeeshan., Yasir Akram., Maryam Amjad dan Muhammad Usman. 2013. Ownership structure and dividend policy, Interdisciplinary Journal of Contemporary Research in Busnine 5(3), 378-401.

Asiah, Antung N. 2015. Analisis Pengaruh Current Ratio, Quick Ratio, Debt To Equity Ratio dan Return On Equity Terhadap Dividen Payout Ratio (Studi Empiris Pada Perusahaan Manufaktur di BEI). Jurnal Ilmu-Ilmu Sosial. 7(1), 19-30.

Atmaja, L.S. 2008. Teori dan Praktik Manajemen Keuangan, Edisi Pertama, Penerbit ANDI, Yogyakarta.

Brigham, E.F., dan J. Houston. (Ali Akbar Yulianto, Penerjemah). 2011. Manajemen Keuangan. Edisi Kesebelas. Jakarta: Salemba Empat.

Corina, Ioanas; Nichita Mirela dan Gruiescu Michaela. 2004. Factors That Affect Dividend Policies. Romanian Economic and Business Review. 4(2).

Deitiana, Tita. 2009. Faktor-Faktor yang Mempengaruhi Kebijakan Pembayaran Dividen Kas, Jurnal Bisnis dan Akuntansi 1(1), 38-63.

Dewi, Sisca C. 2008. Pengaruh Kepemilikan Managerial, Kepemilikan Institusional, Kebijakan Hutang dan Profitabilitas dan Ukuran Perusahaan Terhadap Kebijakan Dividen. Jurnal Bisnis dan Akuntansi. 1(1), 47-58.

Dewi, Trisna, N.W. 2014. Pengaruh Struktur Modal, Likuiditas, dan Pertumbuhan Terhadap Kebijakan Dividen Di Bei. Skripsi. Jurusan Manajemen Fakultas Ekonomi Universitas Udayana, Denpasar.

Gitman, L.J., 2006, Principles of Managerial Finance, $11^{\text {th }}$ Edition: Addison Wesley: New York. 
Gugler K. 2003, Corporate Governance, Dividend Smoothing, and the Interrelation between Dividends, R\&D, and Capital Investment, Journal of Banking and Finance, 27(7), 1297 - 1321.

Handayani, R., \& Indahningrum, R. P. (2009). Pengaruh Kepemilikan Manajerial, Kepemilikan Institusional, Dividen, Pertumbuhan Perusahaan, Free Cash Flow dan Profitabilitas Terhadap Kebijakan Hutang Perusahaan. Jurnal Bisnis Dan Akuntansi, 11(3), 189-207.

Hendrianto, Samino. 2013. Analisis Cash Ratio, Debt To Equity Ratio, Return On Asset, Growth dan Pengaruhnya Terhadap Dividen Payout Ratio Pada Perusahaan Pertambangan yang Terdaftar Di Bursa Efek Indonesia. Jurnal TEKUN 4(2), 232-246.

Ida Ayu Agung Idawati Drs. Gede Merta Sudiartha, M. (2011). Pengaruh profitabilitas, likuiditas, ukuran perusahaan terhadap kebijakan dividen perusahaan manufaktur di bei. Pengaruh Profitabilitas, Likuiditas, Ukuran Perusahaan Terhadap Kebijakan Dividen Perusahaan Manufaktur Di Bei, 1604-1619.

Igan, Deniz., Aureo de Paula dan Marcelo Pinheriro. 2010. Liquidity and Dividend Policy, Munich Personal RePEc Archive, 2(9), 1-48.

Ihejirika,Peters .O dan Nwakanma Prince C. 2012. An Empirical Analysis of the Propensity to Pay or Not to Pay Dividens: A test of the life cycle theory with Nigerian data. Arabian Journal of Business and Management Review (Oman Chapter). 1(12): 74-87

Islam, D. K. M. Z., \& Saha, T. K. (2014). An Empirical Analysis of Determinants of Dividend Policy: Evidence from the Bangladeshi Private Commercial Banks. 3(00971501545637), 1-22.

Kasmir. 2011. Analisis Laporan Keuangan. Cetakan ke 3. Jakarta: PT.Raja Grafindo Persada.

Lopolusi, I. (2013). Analisis faktor-faktor yang mempengaruhi kebijakan dividen sektor manufaktur yang terdaftar BEI periode 207-2011. Calyptra: Jurnal Ilmiah Mahasiswa Universitas Surabaya, 2(1), 1-18.

Maldajian, C., \& El Khoury, R. (2014). Determinants of the Dividend Policy: An Empirical Study on the Lebanese Listed Banks. International Journal of Economics and Finance, 6(4), 240-256. https://doi.org/10.5539/ijef.v6n4p240

Marpaung, E. I., \& Hadianto, B. (2009). Pengaruh profitabilitas dan kesempatan investasi terhadap kebijakan dividen: studi empiris pada emiten pembentuk indeks LQ45 di bursa efek indonesia. Jurnal Akuntansi, 1(1), 70-84. 
Mehta, Anupam. 2012. An Empirical Analysis of Determinants of Dividend Policy: Evidence from the UAE Companies, Global Review of Accounting and Finance. 3(1), $18-31$.

Murni, Sri dan Andriana. 2007. Pengaruh Insider Ownership, Institutional Investor, Dividend Payment, dan Firm Growth terhadap Kebijakan Hutang Perusahaan (Studi Kasus pada Perusahaan Manufaktur yang terdaftar di Bursa Efek Jakarta). Jurnal akuntansi dan bisnis, 7(1), 15-24.

Murtini, Ni Komang Ayu. 2015. Pengaruh Rasio Keuangan Terhadap Dividen Payout Pada Sektor Industri Barang Konsumsi yang Terdaftar Di BEI. Skripsi. Jurusan Manajemen Universitas Bina Darma, Palembang.

Nuringsih, Kartika. 2005. Pengaruh Kepemilikan Managerial, Kebijakan Hutang, ROA dan Ukuran Perusahaan Terhadap Kebijakan Dividen : Studi 19951996. Jurnal Akuntansi dan Keuangan Indonesia Juli-Desember, 2(2), 103123.

Riyanto, Bambang. 2011. Dasar-Dasar Pembelanjaan Perusahaan. Edisi ke 4. Yogyakarta: BPFE.

Sadalia, Isfenti dan Nurul Sari Syafitri Saragih. 2008. Pengaruh Profitability, dan Investment Opportunity Set Terhadap Dividen Tunai Pada Perusahaan Terbuka di BEI. Jurnal Manajemen Bisnis. 1(3), 103-108.

Sandy, Ahmad dan Nur Fadjrih Asyik. 2013. Pengaruh Profitabilitas Dan Likuiditas Terhadap Kebijakan Dividen Kas Pada Perusahaan Otomotif. Jurnal Ilmu dan Riset Akuntansi. 1(1), 58-76.

Sanjaya, Budi. 2009. Analisis Faktor yang Mempengaruhi Kebijakan Dividen Pada Perusahaan Publik di Indonesia, Kajian Akuntansi, 4(1), 15-24.

Sari, Herlin Puspita. 2008. Pengaruh Likuiditas, Leverage, Profitabilitas, Earnings, Harga Saham, dan SBI Terhadap Jumlah Dividen Tunai (Studi Kasus Pada Seluruh perusahaan yang Terdaftar di Bursa Efek Jakarta Periode 20022005). Skripsi. Jurusan Manajemen Fakultas Ekonomi Universitas Katolik Soegijapranata, Semarang.

Sari, Komang. A.N. 2015. Pengaruh Likuiditas, Leverage, Pertumbuhan Perusahaan, dan Profitabilitas Terhadap Kebijakan Dividen Pada Perusahaan Manufaktur Di BEI. E-Jurnal Manajemen Unud, 4(10), 3346 - 3374.

Sawir, Agnes. 2009. Analisis Kinerja Keuangan dan Perencanaan Keuangan Perusahaan. PT. Gramedia Pustaka Utama. Jakarta. 
Saxena, Atul.K. 2002. Agency Cost, Market Risk, Investment Opportunities, and Dividend Policy - An International Perspective. Managerial Finance, 25(6), 35-43.

Silaban, Dame Prawira. 2016 Pengaruh Profitabilitas, Struktur Kepemilikan, Pertumbuhan Perusahaan dan Efektivitas Usaha Terhadap Kebijakan Dividen Pada Perusahaan Manufaktur. E-Jurnal Manajemen Unud, 5(2), 2302-8912.

Suharli, Michell dan Harahap, Sofyan F. 2004. Studi Empiris Terhadap Faktor Penentu Kebijakan Jumlah Dividen. Media Riset Akuntansi, Auditing, dan Informasi. 4(3), 223-245.

Sulistiyowati, Indah. Anggraini, Ratna dan Utaminingtyas, Tri H. 2010. Pengaruh Profitabilitas, Leverage, dan Growth Terhadap Kebijakan Dividen dengan Good Corporate Governance sebagai Variabel Intervening. Simposium Nasional Akuntansi XIII. Purwokerto.

Sunarya, Devi. H. 2013. Pengaruh Kebijakan Utang, Profitabilitas dan Likuiditas Terhadap Kebijakan Dividen Dengan Size Sebagai Variabel Moderasi Pada Sektor Manufaktur Periode 2008-2011. Jurnal Ilmiah Mahasiswa Universitas Surabaya. 2(1).

Tandelilin, Eduardus. 2010. Portofolio dan Investasi Teori dan Aplikasi. Edisi Pertama. Yogyakarta: BPFE.

Van Horne, James C. and John M. Wachowicz. (Dewi Fitriasari dan Deny Arnos Kwary, Penerjemah). 2005. Fundamentals of Financial: Management Prinsip-Prinsip Manajemen Keuangan. Penerbit Salemba Empat: Jakarta.

Warsono. 2003. Manajemen Keuangan Buku I. Edisi ke 3. Malang: Bayumedia.

Wiagustini, Ni Luh Putu. 2010. Dasar-Dasar Manajemen Keuangan. Denpasar: Udayana University Press.

Wicaksana, I Gede Ananditha. 2012. Pengaruh Cash Ratio, Debt to Equity Ratio, dan Return On Asset Terhadap Kebijakan Dividen Pada Perusahaan Manufaktur Di Bursa Efek Indonesia. Tesis. Program Pasca Sarjana Universitas Udayana, Denpasar.

Wijanti, N. W. N., \& Sedana, I. . P. (2013). Pengaruh Likuiditas, Efektivitas Aktiva dan Ukuran Perusahaan Terhadap Kebijakan Dividen dan Harga Saham. E-Journal Fakultas Ekonomi Dan Bisnis Universitas Udayana, 1649-1661. 